\title{
Anatomical Study and Characterization of Metabolites in Leaves of Momordica charantia L.
}

\author{
Rafaela Damasceno Sá1, Marília Barbosa Cadena' ${ }^{1}$, Rafael José Ribeiro Padilha² , Luiz Carlos Alves², Karina Perrelli \\ Randau $^{1 *}$
}

\section{Rafaela Damasceno Sá1, Marília Barbosa Cadena ${ }^{1}$, Rafael José Ribeiro Padilha , Luiz Carlos Alves ${ }^{2}$, Karina Perrelli Randau1,*}

'Laboratório de Farmacognosia, Departamento de Ciências Farmacêuticas, Universidade Federal de Pernambuco, Avenida Professor Arthur de Sá, Cidade Universitária, Recife, PE, BRAZIL. ${ }^{2}$ Setor de Microscopia Eletrônica, Laboratório de Imunopatologia Keizo Asami, Universidade Federal de Pernambuco, Recife, Pernambuco, BRAZIL.

\section{Correspondence:}

Karina Perrelli Randau Universidade Federal de Pernambuco, Departamento de Ciências Farmacêuticas, Laboratório de Farmacognosia, Av. Prof. Arthur de Sá S/N, CDU, Recife-PE, BRAZIL.

CEP: $50740-521$.

Email: krandau@hotmail.com

\section{History}

- Submission Date: 19-03-2018;

- Review completed: 22-05-2018.

- Accepted Date: 16-07-2018.

DOI : 10.5530/pj.2018.5.140

Article Available online http://www.phcogj.com/v10/i5

\section{Copyright}

(c) 2018 Phcog.Net. This is an open-access article distributed under the terms of the Creative Commons Attribution 4.0 International license.

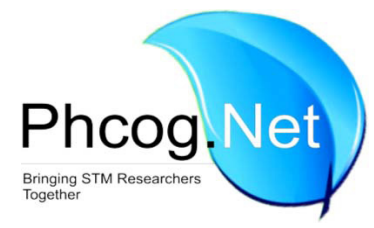

\begin{abstract}
Background: Momordica charantia L. (Cucurbitaceae), is an herbaceous plant used for food and traditional medicine. It presents a proven antidiabetic activity in the literature, being a promising species for the development of phytotherapics. Objective: The objective was performing an anatomical study and characterizing the metabolites in leaves of $M$. charantia. Materials and Methods: Semipermanent histological slides were prepared for analysis of petiole and leaf blade in optical, polarization and scanning electron microscopy coupled with energy-dispersive X-ray spectrometry. Maceration and histochemical tests were also performed in the leaf blade. Results: The anatomical characterization revealed information about the type of trichomes, cuticle, vascular bundles and arrangement of the idioblasts and tissues that determine the botanical identity of this species. The histochemistry allowed determining the location of the metabolites and, along with the chemical microanalyses, to identify the type of crystal in the leaf blade. Conclusion: The study described new characters for $M$. charantia and the results provide support to quality control of the species.
\end{abstract}

Key words: Anatomy, Bitter melon, Crystals, Histochemistry, Melão-de-São-Caetano.

\section{INTRODUCTION}

The family Cucurbitaceae contains species of economic importance in Brazil, especially those belonging to the genera Cucurbita L., Momordica L., Fevillea L. and Sechium P. Br. ${ }^{1}$ Momordica species are vegetable crops which comprise of medium-sized plants that are widely distributed throughout tropical and subtropical regions. ${ }^{2}$ Among them stands out $M$. charantia L., a herbaceous climbing plant, 3-4 m long. It is commonly known as "bitter gourd" or "bitter melon" in English and "Melão-de-são-caetano" in Brazil, where it is cultivated for consumption as fruits and vegetables. ${ }^{3-4}$ It is also a widespread weed in orchards, coffee plantations, over fences and wastelands. ${ }^{5}$

The leaves of the species are used in folk medicine as an antidiabetic ${ }^{5-6}$ and for malaria, ${ }^{7}$ worms, ${ }^{8-9}$ itchy skin, ${ }^{10-11}$ external inflammations, ${ }^{12}$ rheumatism ${ }^{9,13}$ and indigestion. ${ }^{14}$ According to Mentreddy, ${ }^{15}$ M. charantia is probably the most investigated plant among the plants known for their antidiabetic activities. There are several review studies on the antidiabetic potential of the species and also on other activities. ${ }^{3,16-22}$ This species is one of 71 species of plants present in the National Relation Medicinal Plants of Interest to Unified Health System, which have the potential to become a phytotherapic. ${ }^{23,24}$ Considering the purpose of contributing to the quality control of raw material of medicinal importance, this study had the objective of performing an anatomical study and characterizing the metabolites present in leaves of $M$. charantia.

\section{MATERIALS AND METHODS}

\section{Plant material}

Adult leaves of specimens of Momordica charanthia L., Cucurbitaceae, were collected in the neighborhood of Várzea ( $\left.8^{\circ} 02^{\prime} 34.5^{\prime \prime} \mathrm{S}, 34^{\circ} 56^{\prime} 52.9^{\prime \prime} \mathrm{W}\right)$, Recife, Pernambuco, Brazil. A voucher specimen was deposited in the Herbarium Dárdano de Andrade Lima of the Instituto Agronômico de Pernambuco (IPA), under collection number 89980.

\section{Anatomical characterization - optical microscopy}

Cross-sections were obtained by hand, using a common razor blade, at the middle region of petiole and leaf blade fixed in FAA $50 .{ }^{25}$ Leaf blade paradermal sections were also performed on the adaxial and abaxial surfaces. All sections were clarified with sodium hypochlorite solution $(50 \%)^{26}$ followed by washing with distilled water. Lastly, cross-sections were stained with safranin and astra blue ${ }^{27}$ and paradermal sections were stained with methylene blue (1\%). ${ }^{28}$ Semipermanent histological slides were pre- 
pared to contain the sections of botanical material, following common plant anatomy procedures. ${ }^{25,29}$ The analysis of the semipermanent histological slides was conducted on images in software (Toup View Image), obtained by a digital camera coupled to an optical microscope (Alltion). Measurements of the diameter of the crystals were determined using the LAS EZ program and the mean and standard deviation were calculated.

\section{Anatomical characterization - polarized light microscopy}

Semipermanent histological slides were prepared with cross-sections of leaf blades obtained by the same method used for the analysis in optical microscopy, without staining. ${ }^{30}$ The analysis of the slides was conducted using a polarized microscope (Leica DM750M) coupled with a digital camera (Leica ICC50 W), through images processed in software (LAS $\mathrm{EZ).}$

\section{Anatomical characterization - Scanning Electron Microscopy}

Samples of fresh leaf blades were fixed in 2.5\% glutaraldehyde (buffered with $0.1 \mathrm{M}$ sodium cacodylate) and post-fixed using $2 \%$ osmium tetroxide solution (buffered with $0.1 \mathrm{M}$ sodium cacodylate). After dehydration in ethanol series, the material was submitted to critical point drying (Bal-Tec CPD 030) and mounted onto SEM stubs, using doublesided adhesive tape and sputter-coated with gold (Leica EM SCD 500). ${ }^{31}$ Finally, the samples were examined with a scanning electron microscope (Quanta 200 FEG) in the Centro de Tecnologias Estratégicas do Nordeste (CETENE).

\section{Maceration}

The maceration was performed using fresh leaf blades fragments that were disintegrated with the mixture of $10 \%$ nitric acid and $10 \%$ chromic acid (1:1), according to the method of Jeffrey. ${ }^{25}$ Semipermanent histological slides were prepared and images were obtained by a digital camera coupled to an optical microscope (Alltion).

\section{Histochemical characterization}

Histochemical tests were made on cross-sections of fresh leaf blades obtained by hand, using a common razor blade..$^{25}$ The specific reagents used were: potassium dichromate $(10 \%)$ for phenolic compounds, ${ }^{32}$ Sudan III for lipophilic substances, ${ }^{29}$ Dragendorff's reagent for detecting alkaloids, ${ }^{33}$ vanillin-chloridric acid for tannins, ${ }^{34}$ antimony trichloride for triterpenes and steroids, ${ }^{35}$ phloroglucinol for lignin, ${ }^{25}$ Lugol's iodine reagent for $\operatorname{starch}^{25}$ and hydrochloric acid (10\%) to establish the nature of the crystals. ${ }^{36}$

\section{Analysis of the elemental composition of crystals}

Cross-sections of leaf blades were processed following the same methodology described for the analysis in SEM. The chemical microanalyses by Energy Dispersive Spectroscopy (EDS) were done with X-ray detector attached to the Zeiss-EVO-LS15 scanning electron microscope.

\section{RESULTS}

The petiole of $M$. charantia, in cross-section, has a convex outline with two ribs on the adaxial surface and a triangular outline on the abaxial surface (Figure 1A). The epidermis is composed of a single layer of cells and covered with a thin cuticle (Figure 1B). In the epidermis are stomata (Figure 1C), non-glandular and glandular trichomes (Figure 1D,E). The non-glandular trichomes are uniseriate and multicellular (Figure 1D) and the glandular trichomes has uniseriate pedicel and multicellular head (Figure 1E).

The angular collenchyma is discontinuous, observed below the epidermis and composed by one to three layers of cells (Figure 1A,B). The vascular system is constituted by seven bicollateral bundles, arranged in an almost closed circle, being five bundles in the central region of the petiole and two bundles in the ribs (Figure 1A,B). In the parenchyma are observed druses (Figure 1F).

In frontal view, in optical microscopy, the leaf blade of $M$. charantia is hypoestomatic (Figure $2 \mathrm{G}, \mathrm{H}$ ), with anomocytic stomata on the abaxial surface (Figure $2 \mathrm{H}$ ). The epidermal cells have strongly sinuous walls on both sides (Figure 2G,H) and, in SEM, it is verified that they are covered by a slightly striated cuticle (Figure 2I). In optical microscopy and SEM it is also observed, between epidermal cells, some crystalliferous idioblasts in groups of two, three, four, five and six (Figure 2H,J,K,L,M) and the same types of non-glandular and glandular trichomes found in the petiole (Figure 2N,O,P,Q,R,S). The trichomes are more frequent in the region of the midrib (Figure 2R,S).

In cross-section, analyzed under optical microscopy, the midrib of $M$. charantia shows an outline that varies from plane-convex to biconvex (Figure 2A). In the second case, the convexity of the adaxial surface is discrete. The epidermis is uniseriate, with cells with external curved periclinal walls, covered with thin cuticle (Figure 2A). One to two layers of collenchyma are situated below the adaxial epidermis (Figure 2A). In the abaxial region, a discontinuous stratum of collenchyma may also occur in subepidermal position (Figure 2A).

A bicollateral vascular bundle is located in the central parenchyma region of the midrib (Figure 2A). The mesophyll of $M$. charantia, in cross-section visualized in optical microscopy, is dorsiventral, with a layer of palisade parenchyma and up to five layers of spongy parenchyma (Figure 2B). In the abaxial epidermis are inserted idioblasts containing agglomerated crystals (Figure $2 \mathrm{~B}$ ), which are also visualized in polarized microscopy (Figure 2C). The mean diameter of the crystals was $47.28 \pm$ 6.05 .

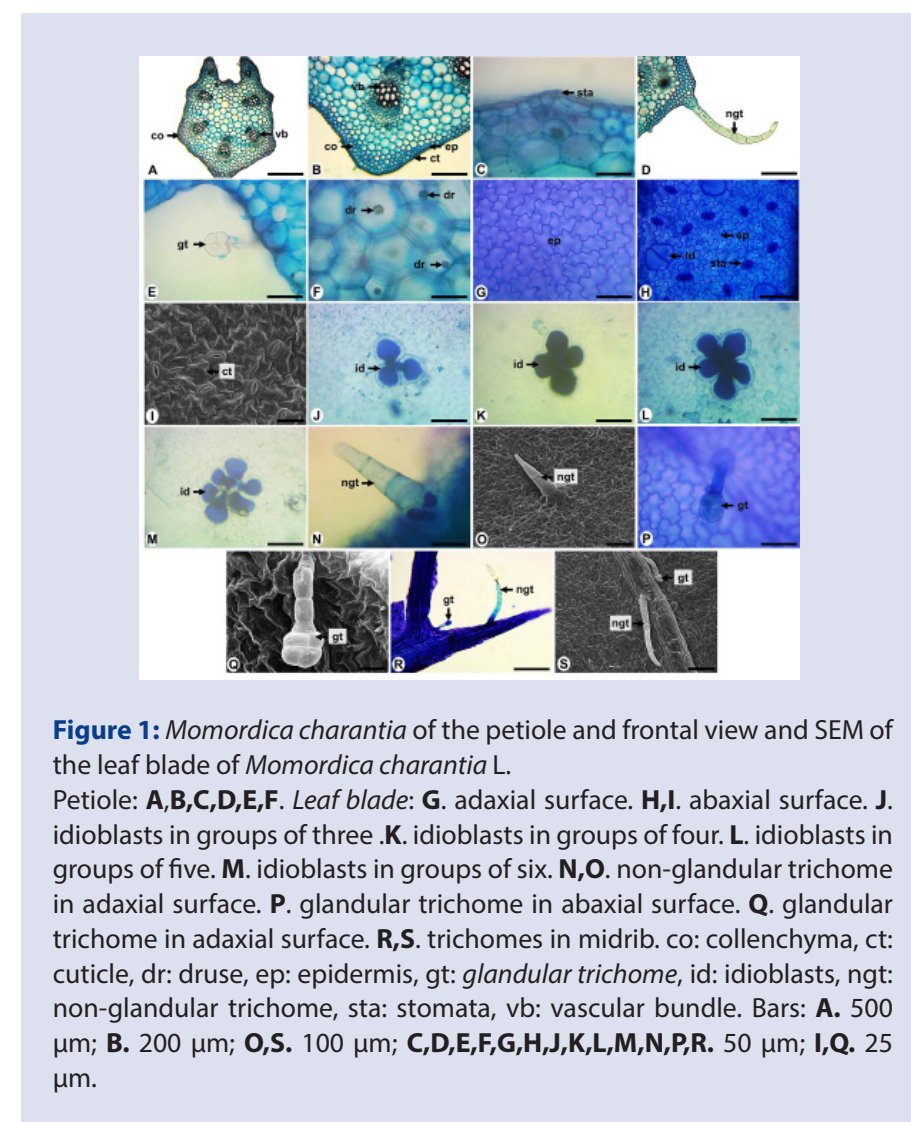




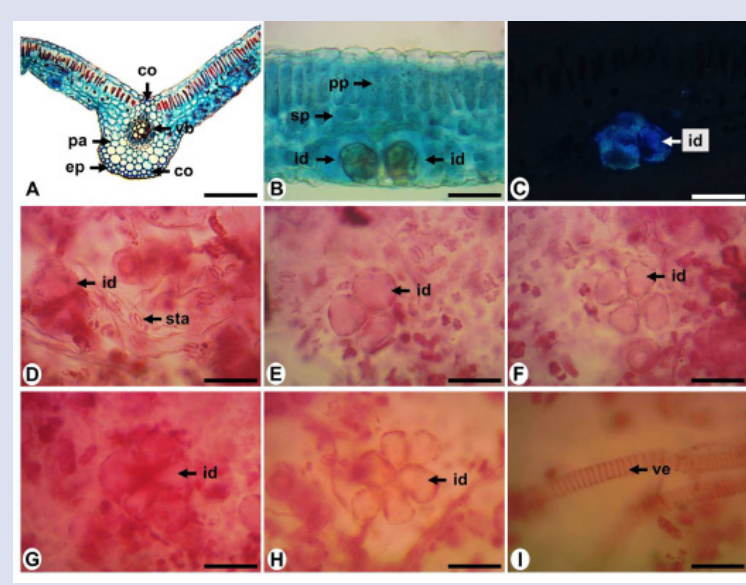

Figure 2: Cross-sections and maceration of the leaf blade of Momordica charantia L.

A. midrib. B. mesophyll. C. idioblasts in polarized microscopy. D. maceration showing stomata and idioblasts in groups of two. E. idioblasts in groups of three. F. idioblasts in groups of four. G. idioblasts in groups of five. $\mathrm{H}$. idioblasts in groups of six. I. vessel element. co: collenchyma, ep: epidermis, id: idioblasts, pa: parenchyma, pp: palisade parenchyma, sp: spongy parenchyma, sta: stomata, vb: vascular bundle, ve: vessel element. Bars: A. $200 \mu \mathrm{m} ; \mathrm{B}, \mathrm{D}, \mathrm{E}, \mathrm{F}, \mathrm{G}, \mathrm{H}, \mathrm{I} .50 \mu \mathrm{m}$; C. $40 \mu \mathrm{m}$

In maceration of the leaf blade, in optical microscopy, were identified fragments of epidermal tissue of the abaxial surface of the leaf blade, where stomata and idioblasts are visualized (Figure 2D). The idioblasts can also be identified when are separated from the epidermal tissue, in groups, in the same way as they are observed in the paradermal sections, as shown in the Figure 2D,E,F,G,H. Vessel elements of the helical type were also identified in maceration (Figure 2I).

The Figure 3A shows a cross-section of the leaf blade without the addition of reagent. Phenolic compounds were found in the epidermal cells (Figure 3B). Besides phenolic compounds, another group of metabolites identified in epidermal cellsof the leaf blade of $M$. charantia was alkaloids (Figure 3C).

Sudan III revealed lipophilic substances in the cuticle (Figure 3D). The phloroglucinol reagent showed the presence of lignin in the xylem (Figure $3 \mathrm{E}$ ). Starch was found in cells of parenchyma in midrib (Figure 3F). The Figure 3G shows the presence of crystals in the idioblasts and Figure $3 \mathrm{H}$ shows the dissolution of the crystals with the test of hydrochloric acid (10\%), indicating that they are of calcium oxalate.

The microanalyses performed by SEM-EDS in the crystals in the idioblasts (Figure 3I) revealed peaks of absorbance for calcium, carbon and oxygen, confirming that they are formed of calcium oxalate (Figure 3J,K).

\section{DISCUSSION/CONCLUSION}

In this study, it was found that the petiole of $M$. charantia has a convex outline with two ribs on the adaxial surface and a triangular outline on the abaxial surface. $M$. tuberosa Cogn. also has a triangular outline on the abaxial surface, but on the adaxial surfaceit has a convex outline. ${ }^{37}$ Sãvulescu and $\mathrm{Hoza}^{38}$ observed that the cuticle is thin in the petiole of $M$. charantia, while Coutinho et al..$^{39}$ described the cuticle as slightly thickened. The presence of collenchyma in the petiole may be a useful feature to distinguish species of Momordica. Aguoru and Okoli ${ }^{40}$ analyzed seven species of Momordica, including $M$. charantia. The authors verified that M. cabrae (Cogn.) C. Jeffrey and M. foetida Schumach. et Thonn. do not have collenchyma, M. angustisepala Harms has only one layer of this tis-

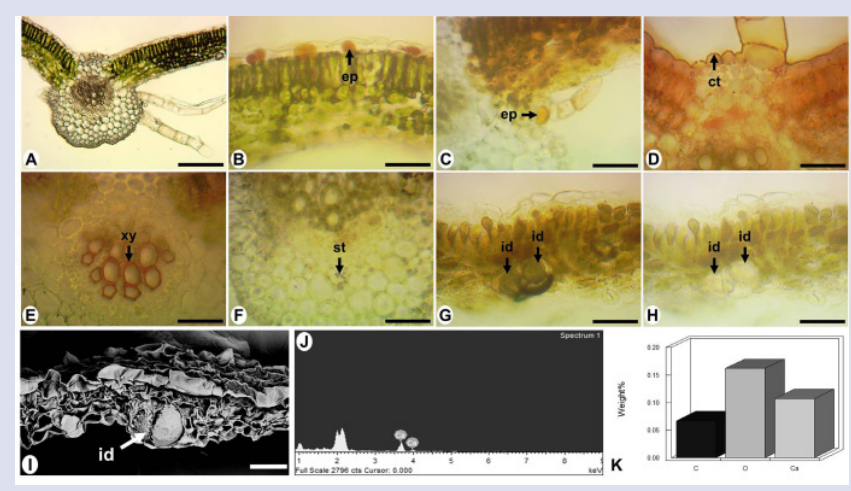

Figure 3: Histochemistry, scanning electron micrograph and elemental composition of the crystals of the leaf blade of Momordica charantia L. A. control. B. potassium dichromate (10\%). C. Dragendorff's reagent. D. Sudan III. E. phloroglucinol. F. Lugol's iodine reagent. G,H. hydrochloric acid (10\%). I. idioblast in mesophyll. J. analysis of elemental composition of the crystal. K. percentage of the chemical constituents of the crystal. ct: cuticle, ep: epidermis, id: idioblasts, st: starch, xy: xylem. Bars: A. 200 $\mu \mathrm{m} ; \mathrm{B}, \mathrm{C}, \mathrm{D}, \mathrm{E}, \mathrm{F}, \mathrm{G}, \mathrm{H} .50 \mu \mathrm{m} ; \mathrm{I} .40 \mu \mathrm{m}$.

sue, M. cissoides Planch. ex Benth. and M. multiflora Hook.f. exhibit one to two layers, $M$. charantia exhibit two layers and M. balsamina L. has three layers of collenchyma. Sãvulescu and $\mathrm{Hoza}^{38}$ found seven bicollateral bundles in the central region of the petiole and two bicollateral bundles in the ribs of $M$. charantia. In the study of Aguoru and Okoli, ${ }^{40}$ with species of Momordica, it was shown that the number of bicollateral bundles ranges from six to eighteen.

According to Metcalfe and Chalk, ${ }^{41}$ non-glandular and glandular trichomes are common in the family Cucurbitaceae and, in this study, they were visualized in the petiole and the leaf blade of M.charantia. The trichomes are more frequent in the region of the midrib, corroborating the data found by Coutinho et al. ${ }^{39}$ Daleffi Zocoler et al. ${ }^{42}$ and Poyraz and Derdovsk $^{43}$ cited only the presence of non-glandular trichomes on the leaf blade of the species. Coutinho et al., ${ }^{39}$ also studying the leaf blade of $M$. charantia, evidenced the same types of trichomes described in the present study.

In Cucurbitaceae, the stomata are of the anomocytic type and may be present on both sides of the leaf blade or restricted to the abaxial surfaceMetcalfe and Chalk. ${ }^{41}$ Daleffi Zocoler et al..$^{42}$ and Sãvulescu and Hoza ${ }^{38}$ described a bicollateral vascular bundle in the central midrib of the leaf blade of the plant. However, Coutinho et al. ${ }^{39}$ reported that there are one to three vascular bundles. In the case of three vascular bundles, the central one is bigger and bicollateral and the other adjacent ones are collaterals. When there is only one vascular bundle, this is always bicollateral.

In $M$. tuberosa, the palisade parenchyma presents two layers of cells and the idioblasts are inserted in both surfaces of the epidermis, ${ }^{37}$ making these characters useful for differentiation of $M$. charantia. Analyzing the powder of the leaf blade of M. tuberosa, Kumar et al. ${ }^{37}$ cited that the idioblasts appear in pairs or, occasionally, in groups of more than three idioblasts.

They were not found in the literature histochemical studies with leaves of $M$. charantia. However, phytochemical studies in the literature indicate the presence of flavonoids, tannins, terpenes and alkaloids. ${ }^{44,45}$ In the present study, tannins and terpenes were not evidenced. This divergence with the literature can be explained by the difference in sensitivity between the histochemical and phytochemical techniques employed.

According to Metcalfe and Chalk, ${ }^{41}$ in the family Cucurbitaceae are found cystoliths of calcium carbonate. However, the microanalyses by 
SEM-EDS and the histochemical test showed that the crystals present in the leaf blade of the species are of calcium oxalate. Calcium oxalate crystals are common in plants and present in various forms and come from the combination of the oxalic acid resulting from the metabolism with the calcium ions absorbed by the plants. ${ }^{46}$ The most common forms are druses, raphides, crystalline sand and prismatic crystals. However, the crystal shape observed in the leaf blade of $M$. charantia is an exception. The diversity of shapes and sizes of calcium oxalate crystals, as well as its prevalence, is correlated with diverse functions in plants, such as cellular ion balance, osmotic regulation, vegetable defense against herbivory, tissue mechanic support, detoxification of aluminum and heavy metals, capture and reflection of solar energy. ${ }^{46,47}$

Through different microscopic techniques, this study described new characters for $M$. charantia, increasing the data of the literature on the family Cucurbitaceae. Being this a species of ample medicinal use, the results will help in further standardization of the plant.

\section{ACKNOWLEDGEMENT}

The authors are grateful to Coordenação de Aperfeiçoamento de Pessoal de Nível Superior (CAPES) and to Conselho Nacional de Desenvolvimento Científico e Tecnológico (CNPq) for financial support in the form of fellowship awards. They also thanks to Fundação de Amparo à Ciência e Tecnologia (FACEPE) for research funding (APQ- 0220-4.03/15) and to CETENE for the analysis in SEM.

\section{REFERENCES}

1. Souza VC, Lorenzi H. Botânica sistemática: guia ilustrado para identificação de famílias de Angiospermas da flora Brasileira, baseado em APG II. Nova Odessa: Instituto Plantarum; 2005.

2. Nagarani G, Abirami A, Siddhuraju P. Food prospects and nutraceutical attributes of Momordica species: a potential tropical bioresources - a review. Food Sci Hum Wellness. 2014;3:117-26.

3. Beidokht MN, Jäger AK. Review of antidiabetic fruits, vegetables, beverages, oils and spices commonly consumed in the diet. J Ethnopharmacol. 2017;201:26-41.

4. Lorenzi H, Lacerda MTC, Bacher LB. Frutas no Brasil: nativas e exóticas (de consumo in natura). São Paulo: Instituto Plantarum de Estudos da Flora; 2015.

5. Lorenzi H. Plantas daninhas do Brasil: terrestres, aquáticas, parasitas e tóxicas. Nova Odessa: Instituto Plantarum.2008.

6. Lorenzi H, Matos FJA. Plantas medicinais no Brasil: nativas e exóticas. São Paulo: Plantarum; 2002.

7. Santos MRA, Lima MR, Oliveira CLLG. Medicinal plants used in Rondônia, Western Amazon, Brazil. Rev Bras PI Med. 2014;16:707-20.

8. Aguiar LCGG, Barros RFM. Plantas medicinais cultivadas em quintais de comunidades rurais no domínio do cerrado piauiense (Município de Demerval Lobão, Piauí, Brasil). Rev Bras PI Med. 2012;14:419-34.

9. Messias MCTB, Menegatto MF, Prado ACC, Santos BR, Guimarães MFM. Uso popular de plantas medicinais e perfil socioeconômico dos usuários: um estudo em área urbana em Ouro Preto, MG, Brasil. Rev Bras PI Med 2015;17:76-104.

10. Albuquerque UP, Monteiro JM, Ramos MA, Amorim ELCA. Medicinal and magic plants from a public market in northeastern Brazil. J Ethnopharmacol. 2007; 110:76-91.

11. Liporacci HSN, Simão DG. Levantamento etnobotânico de plantas medicinais nos quintais do Bairro Novo Horizonte, Ituiutaba, MG. Rev Bras PI Med. 2013;15:529-40.

12. Cordeiro JMP, Félix LP. Conhecimento botânico medicinal sobre espécies vegetais nativas da caatinga e plantas espontâneas no agreste da Paraíba. Brasil. Rev Bras PI Med. 2014;16:685-92.

13. Oliveira FCS, Barros RFM, Moita Neto JM. Plantas medicinais utilizadas em comunidades rurais de Oeiras, semiárido piauiense. Rev Bras PI Med. 2010;12:282-301.

14. Gomes TMF, Lopes JB, Barros RFM, Alencar NL. Plantas de uso terapêutico na comunidade rural Bezerro morto, São João da Canabrava, Piauí, Brasil. Gaia Scientia. 2017;11:253-68.

15. Mentreddy SR. Medicinal plant species with potential antidiabetic properties. J Sci Food Agric. 2007;87:743-50.
16. Grover JK, Yadav SP. Pharmacological actions and potential uses of Momordica charantia: a review. J Ethnopharmacol. 2004;93:123-32.

17. Gupta M, Sharma S, Gautam AK, Bhadauria R. Momordica charantia Linn. (karela): nature's silent healer. Int J Pharm Sci Rev Res. 2011;11:32-7.

18. Joseph B, Jini D. Antidiabetic effects of Momordica charantia (bitter melon) and its medicinal potency. Asian Pac J Trop Dis. 2013;3:93-102.

19. Panday DR, Rauniar GP, Panday KR. Momordica charantia (karela): and antidiabetic. World J Pharm Sci 2015;4:84-99.

20. Upadhyay A, Agrahari P, Singh DK. A review on salient pharmacological features of Momordica charantia. Int J Pharm. 2015;11:405-13.

21. Ahmad N, Hasan N, Ahmad Z, Zishan M, Zohrameena S. Momordica charantia: for traditional uses and pharmacological actions. J Drug Deliv Ther. 2016;6:40-4.

22. Tan SP, Kha TC, Parks SE, Roach PD. Bitter melon (Momordica charantia L.) bioactive composition and health benefits: a review. Food Rev Int. 2016;32:181202.

23. Brasil. Plantas de interesse ao SUS. Ministério da Saúde; 2009.

24. Marmitt DJ, Rempel C, Goettert MI, Silva AC. Revisão sistemática sobre a produção científica de plantas medicinais da RENISUS voltadas ao Diabetes mellitus. Caderno Pedagógico Lajeado. 2015;12:87-99.

25. Johansen DA. Plant microtechnique.New York: McGraw-Hill; 1940.

26. Kraus JE, Arduin M. Manual básico de métodos em morfologia vegetal. Rio de Janeiro: EDUR; 1997.

27. Bukatsch F. Bemerkungen zur doppelfärbung Astrablau-Safranin. Mikrokosmos. 1972;61:255.

28. Krauter D. Erfahrungen mit Etzolds FSA-Färbung für pflanzenschnitte. Mikrokosmos. 1985; 74:231-3.

29. Sass JE. Botanical microtechnique. Ames: lowa State College Press; 1951.

30. Zhang J, Lu H, Huang L. Calciphytoliths (calcium oxalate crystals) analysis for the identification of decayed tea plants (Camellia sinensis L.). Sci Rep. 2014;4:1-9.

31. Haddad A, Sessos A, Attias M, Farina M, Nazareth MM, Silveira M, et al. Técnicas básicas de microscopia eletrônica aplicadas às Ciências Biológicas. Rio de Janeiro: Sociedade Brasileira de Microscopia Eletrônica; 1998.

32. Gabe M. Techniques histologiques. Paris: Masson and Cie; 1968.

33. Yoder LR, Mahlberg PG. Reactions of alkaloid and histochemical indicators in laticifers and specialized parenchyma cells of Catharanthus roseus (Apocynaceae). Am J Bot. 1976;63:1167-1173.

34. Mace MZ, Howell CR. Histochemistry and identification of condensed tannin precursors in roots of cotton seedlings. Can J Bot. 1974;52:2423-2426.

35. Mace ME, Bell AA, Stipanovic RD. Histochemistry and isolation of gossypol and related terpenoids in root of cotton seedlings. Phytopathology. 1974;64:1297302.

36. Jensen WA. Botanical histochemistry: principles and practice. San Francisco: W. H. Freeman and Co; 1962.

37. Kumar P, Rao D, Bilakanti L, Setty R. Pharmacognostical studies on Momordica tuberosa Cogn. Pharmacogn J.2010;2:28-33.

38. Sãvulescu E, Hoza G. Research results regarding the anatomy of Momordica charanthia L. specie. Lucrări ştiințifice USAMVB, Seria B, LIV. 2010;694-700.

39. Coutinho DF, Florêncio JC, Aguiar LR, Rodrigues KAF, Vilanova CM, Borba ERC. Estudo farmacobotânico das folhas de Momordica charantia L. (Cucurbitaceae). Visão Acadêmica. 2009;10(1):7-17.

40. Aguoru CU, Okoli BE. Comparative stem and petiole anatomy of West African species of Momordica L (Cucurbitaceae). Afr J Plant Sci. 2012;6(15):403-9.

41. Metcalfe CR, Chalk L. Anatomy of the dicotyledons: leaves, stem, and wood in relation to taxonomy with notes on economic uses. Oxford: Clarendon Press; 1950.

42. Daleffi ZAM, Mourão KSM, Mello JCP, Marques LC. Contribuição ao controle de qualidade farmacognóstico das folhas e caules de Melão-de-São-Caetano (Momordica charantia L. - Cucurbitaceae). Acta Farm Bonaer. 2006;25:22-7.

43. Poyraz IE, Derdovski C. Morpho-anatomical investigations on Momordica charantia L. (Cucurbitaceae). Anadolu Univ. J of ScTechnology - C - Life Sci and Biotech.2016;5:23-30.

44. Alencar NL, Araújo TAS, Amorim ELC, Albuquerque UP. The inclusion and selection of medicinal plants in traditional pharmacopoeias - evidence in support of the diversification hypothesis. Econ Bot. 2010;64(1):68-79.

45. Rodrigues KAF, Dias CN, Florêncio JC, Vilanova CM, Gonçalves JRS, Moraes DFC. Prospecção fitoquímica e atividade moluscicida de folhas de Momordica charantia. Cadernos de Pesquisa. 2010;17(2):69-76.

46. Franceschi VR, Nakata PA. Calcium oxalate in plants: formation and function. Annu Rev Plant Biol. 2005;56:41-71.

47. Franceschi VR, Horner HT Jr. Calcium oxalate in plants. Bot Rev. 1980;46:361427.

Cite this article: Rafaela DS, Marília BC, Rafael José RP , Luiz CA, Karina Perrelli R Anatomical Study and Characterization of Metabolites in Leaves of Momordica charantia I. Pharmacog J. 2018;10(5):823-6 